\title{
Die pastorale begeleiding van predikante van die Nederduitse Gereformeerde Kerk tydens die kerklike tughandeling
}

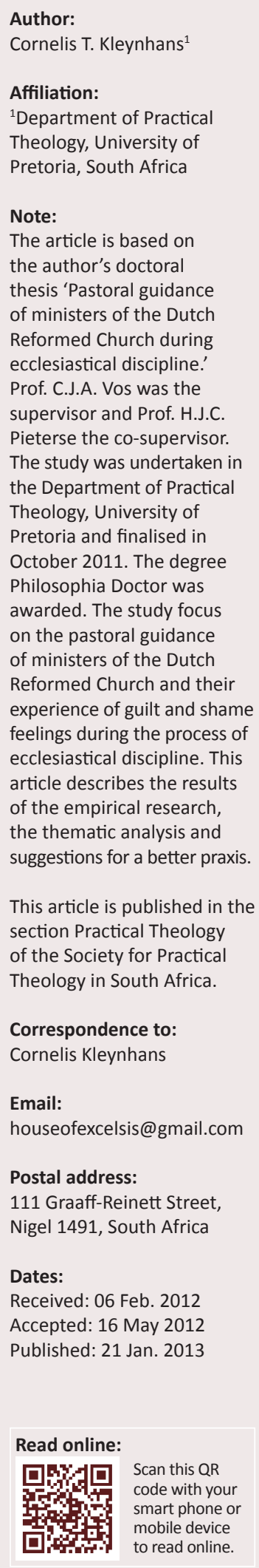

Author:

S. Kleynhans

Theology, University of

Note:

thesis 'Pastoral guidanc

of ministers of the Dutch

Prof. C.J.A. Vos was the supervisor and Prof. H.J.C.

Pieterse the co-superviso

Theology, University of

Pretoria and finalised in

awarded. The study focus

on the pastoral guidance

of ministers of the Dutch

feelings during the process of

ecclesiastical discipline. This

the thematic analysis and

This article is published in the section Practical Theology of the Society for Practical

Correspondence to:

Email:

Postal address:

111 Graaff-Reinett Street,

Dates:

Received: 06 Feb. 2012

Accepted: 16 May 2012

Published: 21 Jan. 2013

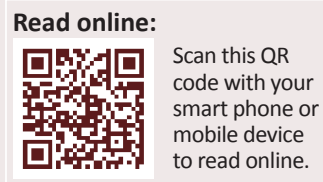

\begin{abstract}
Pastoral guidance of ministers of the Dutch Reformed Church during ecclesiastical discipline. The process of ecclesiastical discipline evokes feelings of guilt and shame. Whilst literary study suggested this to be the case, the empirical research confirmed it. It is clear that the three-fold process was a traumatic and shocking experience for ministers. Most upsetting was the way that the process was handled. It was done in a non-professional way and without brotherly or sisterly love. The process triggered guilt and shame emotions in a number of ways, not least by the lack of support and guidance. Respondents indicated that they had positive and negative experiences of guilt and shame during the discipline process. Most respondents took action to amend their mistakes, and thereby used the guilt feeling functionally, whilst the use of defence mechanisms showed that they did not manage and process the feelings of shame. It is unsettling to realise that the Dutch Reformed Church fails her ministers in time of need. Only a few parishioners and ministers from other denominations provided some sort of comfort during the discipline process. The church gave no support and guidance in the processing of the feelings of guilt and shame. The church lacked in every aspect, even to show a basic understanding of the trauma, and none of the church councils offered any basic or interventive help. To remedy the situation, it is proposed that the church should take its task as caregiver during the ecclesiastical discipline of ministers very serious and give guidance in an official and professional way.
\end{abstract}

\section{Inleiding}

Predikante is nie sondelose mense nie en daarom word in Die Kerkorde van die Nederduitse Gereformeerde Kerk (N.G. Kerk) vir die tughandeling en tugmaatreëls voorsiening gemaak (Niemandt 2007:2430). Foutiewe oordele en sonde dek die tafel vir die diskreditering van die predikant as persoon, die amp van bedienaar, die gemeenskap van gelowiges en die kerkverband in die breë. Wanneer gerugte soos ' $n$ veldbrand versprei of ' $n$ klagstaat op die tafel van die Kerkraad beland, veroorsaak dit 'n krisis en trauma vir die predikant as mens, as ampsdraer, gesinsmens, eggenoot en gemeenskapsleier. Die rimpels van die klippie wat in die tugpoel gegooi word, strek wyd en ver en die gevolge daarvan ontsien niks of niemand nie.

Die predikant het soveel om te verloor tydens die tughandeling. Hieronder tel haar of sy bediening, invloed en gesag as draer van die evangelieboodskap, integriteit en waardigheid, asook die respek en agting wat sy of hy voorheen ontvang het. Soms verloor die predikant ook haar of sy eggenoot, gesin, inkomste en sekuriteit en toekomsideale. Die gemeente ervaar die proses eweneens traumaties en skokkend. Die tughandeling het verder ook massiewe bedieningsen finansiële implikasies.

Predikante wat na verlies van hulle ampsbevoegdheid weer heraansoek doen om tot die bediening terug te keer, bevind hulle in 'n nuwe krisis en trauma wat die wonde opnuut oopkrap. Onverwerkte skuld- en skandgevoelens borrel na die oppervlak en veroorsaak erge wroeging. Jare sleep letterlik verby voordat sommige gelukkig genoeg is om tot 'n colloquium doctum toegelaat te word. Die heel gelukkiges verkry weer ampsbevoegdheid as proponente. Om na 'n colloquium doctum vir vakante bedieningsposte aansoek te doen, is moeilik.

Die gevoelens waarmee die predikant gekonfronteer word, veroorsaak persoonlike wroeging. Bitterheid, woede en depressie kan na jare steeds te voorskyn tree. Mediese en sielkundige rekeninge word dikwels deel van die uitgawes.

\section{Navorsingsbehoefte}

Die tughandeling is ' $n$ inherente deel van die aard en funksionering van die kerk (Vorster 1997:163). Dat die tughandeling plaasvind, word dus nie bevraagteken nie, maar hoe dit plaasvind en

How to cite this article: Kleynhans, C.T., 2013, 'Die pastorale begeleiding van predikante van die Nederduitse Gereformeerde Kerk tydens die kerklike tughandeling', HTS Teologiese Studies/Theological Studies 69(2), Art. \#1230, 10 pages. http://dx.doi.org./10.4102/hts.v69i2.1230 Copyright: ๑ 2013. The Authors. Licensee: AOSIS OpenJournals. This work is licensed under the Creative Commons Attribution License. 
watter uitwerking dit het en hoe die kerk dit fasiliteer, word wel ondersoek. Britz (1991:4) vra onder andere: 'Moet ons onsself nie afvra of die prosedures met sy stelle bepalinge nie ongemerk (teen ons eie bedoeling in) tussen ons en die Skrif ingeskuif het nie?' Die skrywer self het die volgende vrae geïdentifiseer en ondersoek:

- Lewer die tughandeling ' $n$ bydrae tot die gevoelsbelewing van skuld en skande by predikante?

- Indien predikante tydens die tughandeling gevoelens van skuld en skande beleef, wat is die aard en funksie van die gevoelens?

- Is daar pastorale begeleiding vir predikante wat tydens die tughandeling moontlike gevoelens van skuld en skande ervaar, en hoe word hulle gehelp om die gevoelens te verwerk?

Tydens die ondersoek is aangetoon dat die tug van predikante uit ' $n$ reeks handelinge bestaan wat oor jare kan strek (Sadler 1979:2) en dit kan in verskillende kleiner stappe verdeel word. Dit is 'n reeks samehangende gebeurtenisse wat in dele, maar ook in samehang beskou moet word.

\section{Metodologiese posisionering}

Heitink (1993:174-230), Pieterse (1993:169-190) en De Wet (2009:227-250) formuleer drie dimensies of fases waarbinne die praktiese teologie sigself metodologies posisioneer:

- Eerstens word die ondersoek gerig deur die teologiese teorie te formuleer.

- Tweedens volg die empiriese ondersoek.

- Derdens word daar vanuit die hermeneutiese interaksie tussen die teologiese teorie en die empiriese ondersoek 'n strategiese voorstel of aangepaste model vir 'n verbeterde praktykteorie ontwikkel.

Op hierdie spoor kan die metodologiese oriëntasie van die studie as ' $n$ prakties-teologiese metode van literatuurondersoek en ' $n$ kwalitatiewe empiriese ondersoek beskryf word.

\section{Empiriese navorsing, resultate en sintese}

Die empiriese navorsing is gedoen deur van ' $n$ kwalitatiewe metode gebruik te maak. Die skrywer het 'n gestruktureerde onderhoudskedule saamgestel met antwoordkategorieë tipe vrae, asook oop tipe vrae. Die onderhoudskedule is saamgestel en in vier afdelings verdeel. Dit is vir hierdie artikel verkort en as Bylaag 1 aangeheg. Daar is gebruik gemaak van 'n teoretiese steekproeftrekking waarvolgens die skrywer se kennis van die situasie van die persone wat die tughandeling deurgegaan het, gebruik is. Ses respondente wat die tughandeling ervaar het, is telefonies genader vir onderhoude wat elk ongeveer ' $n$ uur en 'n half geduur het. Die resultaat van die onderhoude word hieronder verwoord. Die skrywer wil dit beklemtoon dat die direkte woorde en gevoelens van die respondente hieronder weergegee word. Dit is soms emosioneel gelade en persoonlik. Hiermee is die doel van die ondersoek volbring, naamlik om predikante se persoonlike belewing van die emosies van skuld en skande tydens die tughandeling onder woorde te bring. Die konteks van elke tugsaak is nie verwoord nie aangesien dit die etiese onderneming sou teenwerk om die anonimiteit van die respondente te verseker.

\section{Die tughandeling as proses}

Die respondente het vanweë kontekstuele verskille nie dieselfde prosesse in die tughandeling ervaar nie. Nogtans was dit opmerklik dat elke respondent aangedui het dat die tugliggaam ten opsigte van die deel van die prosesse wat op haar of hom van betrekking was, nie die korrekte kerkordelike prosedures ten opsigte van die tughandeling nagekom het nie. Hierdie optrede van die tugliggame is met skok ervaar. Respondente het aangedui dat dit een van die grootste traumas was wat hulle tot dusver beleef het. Hulle was geskok:

- dat die tughandeling plaasgevind het (het nooit gedink dat dit met hulle sal gebeur nie)

- dat die kerkordelike prosedures nie nagekom is nie

- dat hulle beleef het dat die Kerke geen hulp, bystand of begeleiding verleen het nie, maar dat hulle eerder isolasie en verwerping ervaar het en

- en, dat die ervaring van die tughandeling die van liefdeloosheid was.

Daar is deur almal aangedui dat die tugproses hulle diep geraak het en hulle daardeur verander is. Die tughandeling is uiters negatief ervaar en respondente het blywende bitterheid, woede en ook depressie as daaglikse metgesel aangeteken. Hulle het die proses beleef as:

- koud

- onpersoonlik

- gestroop van eerlikheid

- onbillik

- onredelik

- met konflik en gebroke verhoudings besaai

- manipulerend en

- on-Christelik.

Die respondente het gemiddeld 6.25 maande gewag vir die eerste of gedeelte van die eerste proses van die tughandeling om afgehandel te word. Hulle belewing was dat die Ringskommissie hierdie proses doelbewus uitrek. Die redes wat hulle aangee is:

- dat die Ringskommissie reeds bewus was van die feit dat hulle prosedurefoute begaan het en daarom die proses probeer uitrek met die verwagting dat die predikant se trauma so sal vergroot dat sy of hy gewilliglik self sal bedank en die hele saak so opgelos kan word

- dat die Ringskommssie nie bevoeg is om die saak kerkordelik korrek te bestuur nie en daarom met die volgende aksie sloer

- dat die Ringskommissie bloot net nie genoeg omgee nie en daarom nie die gevolge van hierdie uitgerekte proses soos dit die predikant en haar of sy gesin en die gemeente raak, voldoende bestuur nie.

\section{Die tughandeling en die gevoelsbelewing van skuld en skande}

Predikante beleef' $n$ warboel emosies tydens die tughandeling. Die studie het op twee emosies gefokus, naamlik skuld en skande. 


\section{Skuldgevoelens}

Skuldgevoelens is ' $n$ pynlike, innerlike gevoel wat veroorsaak word deur die selfbewuswording van konflik tussen eie optrede en die voorafooreengekome morele en sedelike kode. Skuld is ' $n$ fenomenologiese saak en het met die oortreding van waardesisteme te make. Skuldgevoelens betrek ons gedagtes, gedrag en handelinge en word fisies en kognitief ervaar. Al die respondente het aangedui dat hulle tydens die tughandeling skuldgevoelens beleef het of steeds beleef. Respondente het onder andere skuldig gevoel teenoor:

- gemeentelede

- hul eie kinders en familie

- die Here.

Die respondente het ook ' $n$ redelike tot oorweldigende belewing van skuldgevoelens gehad. Die intensiteitsgraad van die belewing is getemper deurdat sekere respondente:

- alles in hulle vermoë gedoen het om sake reg te stel

- die Here se vergifnis opgesoek het of

- die gebeure as uiters belaglik beskou.

Die meeste respondente het ' $n$ definitiewe fisiese ervaring van ' $n$ deurdringende bitterheid beleef, asook pyn in die abdomen en 'n gevoel van angstigheid. Die helfte van die respondente het hulle hande gewring en die kop het gehang (dit hou weer verband met gevoelens van skaamte). Meer as die helfte het die gebeure in die gedagtes herhaal en die scenario's gedurig verander, terwyl selfverwyt ook beduidend groot tot oorweldigend was.

$\mathrm{Al}$ die respondente het aangedui dat hulle ' $\mathrm{n}$ bitterheid teenoor die lede van die Ringskommissie ervaar. Hierdie gevoel is veroorsaak deur die gevoel dat Ringslede liefdeloos en onregverdig opgetree het en dat respondente persoonlik te na gekom is. Respondente het hulle self oor sekere sake verwyt. Die belangrikste hiervan is die gevoel dat hulle sake anders kon hanteer het en daardeur die hele proses kon vermy het.

Die respondente het almal te kenne gegee dat hulle die skuldemosie op hul eie hanteer en verwerk het. Skuldemosie word binne die Kerk in die algemeen gefasiliteer deur die proses van:

- die aanvaarding van verantwoordelikheid

- erkenning van skuld

- toon van berou

- belydenis van skuld

- ontvangs van genade en vergifnis

- 'n lewe in vryheid en dankbaarheid.

Verder het die respondente oorwegend negatiewe kommentaar gelewer ten opsigte van die ervaring van die proses van die tughandeling en die effek daarvan op hul belewing van skuldgevoelens. Die trefwoorde was telkens:

- geweldige belewing van woede

- aggressie

- intense bitterheid

- oorweldig deur gebeure

- vergroting van skuldgevoelens.

\section{Skandgevoelens}

Skandgevoelens is ' $\mathrm{n}$ belewing van inherente tekorte. Dit is die belewing van mislukking. Skande word beleef as ' $n$ blootlegging van die self as ontoereikend, sleg, onwaardig. Skande is ' $n$ selfbeoordeling van die eiewaarde. Skande is hoofsaaklik ' $n$ ontologiese saak. Dit het te doen met ' $n$ persoon se identiteit en menswees.

Die meerderheid respondente het aangedui dat hulle skandgevoelens tydens die tughandeling ervaar het wat:

- groot twyfel in die gemoed meegebring het

- 'n diepe bevraagtekening van die eie bekwaamheid veroorsaak het

- 'n bevraagtekening van selfs die roeping as bedienaar van die Woord veroorsaak het.

Skandgevoelens is as groot tot oorweldigend getipeer ten opsigte van die intensiteitsgraad van die belewing daarvan. Dit was duidelik dat respondente met groter gemak oor skuldgevoelens kon praat as oor skandgevoelens. Skandgevoelens word nie soos skuldgevoelens hanteer nie. Dit blyk dat mense selfs skaam voel om oor skande en skaamte te praat. Om skandgevoelens te bespreek en te erken, hoop nog eens skande op skande. Dat die respondente met hierdie emosie worstel, is duidelik wanneer hul aanduidings van woede en aggressie aangehoor word. Woede is die metgesel van gevoelens van skande en skaamte (T. Scholtemeyer 2011, [navorser se persoonlike gesprekke met me. T. Scholtemeyer na aanleiding van die navorsingstema en persoonlike berading]). Alle respondente het intense gevoelens van woede verwoord.

Sekere respondente het wel aangedui dat hulle gevoel oor hulleself na aanleiding van die tughandeling negatief verander het. Daar was ' $\mathrm{n}$ belewing van gebrekkigheid, onvolkomenheid en defek. Die sterkste belewing was dat alle respondente behalwe een aangedui het dat God hulle nie in hierdie tyd verlaat het nie. Hulle het wel beleef dat mense hulle verwerp en nie meer aanvaar nie.

'n Groot persentasie respondente het aangedui dat hulle talle verdedigingsmeganismes gebruik het om die gevoel van skande te hanteer, waaronder onttrekking en isolasie. Die ervaring van die proses van die tughandeling en die gevoelsbelewing van skande en skaamte het die volgende kernbegrippe opgelewer:

- blywende woede

- blywende seer

- blywende vrae in die gemoed

- jy moet teen wil en dank aangaan

- geweldige persoonlike verlies

- diepe verleentheid

- verwagting van foutloosheid.

Ten opsigte van skuldgevoelens is daar wel positiewe aspekte ook aangedui, naamlik:

- dit dwing tot introspeksie

- besef jou eie menslikheid en dat jy deel is van die gebroke werklikheid

- groter empatie en begrip vir ander 
- wete dat God verstaan

- besef die afhanklikheid van God

- beleef vryspraak en vergifnis

- geloofsgroei ervaar

- groei vind plaas in tye wanneer dit moeilik gaan

- stel dinge uit die verlede reg.

Wat skandgevoelens betref, was die positiewe:

- die dwang tot groter kontak en sosialisering om onskuld te bewys

- groter begrip vir self en ander

- leer mens om voort te gaan ten spyte van gevoelens en omstandighede

- stel in staat om ander beter te kan help

- lei tot groter ondersteuning van ander in nood.

\section{Pastorale begeleiding tydens die tughandeling}

Respondente het die belang van die gemeente as primêre sorggewer ondersteun en ook van 'n kleiner groep lidmate hierdie onvoorwaardelike aanvaarding, versorging en ondersteuning beleef. Die afstand tussen die besondere ampte en die van gelowige word ten tye van die tughandeling egter vergroot omdat:

- lidmate goedgelowig aanvaar dat die Ringskommissie kundig en met liefde sal optree en daarom gelate die proses in die hande van die Kommissie laat

- die geloofsgemeenskap onder groepsdruk en selfs intimidasie swig wanneer negatiewe onderstrominge sterk tydens die tughandeling aanwesig is

- die tughandeling vanweë die skuld, skande en skaamte wat dit ook kollektief oproep enige noue band tussen die ampte ophef.

Respondente het die kerke se versaking van haar roeping om formele en professionele pastorale begeleiding tydens die tughandeling of daarna te bied, verwoord. Sommige het wel bystand ontvang van predikante uit ander kerklike denominasies. Hieroor het respondente hulle ervaring as volg verwoord:

- minimale ondersteuning deur 'n brief, telefoonoproep of enkele besoek of gebed is nie as hulp en begeleiding vertolk nie

- ongevoeligheid en liefdeloosheid by Ringspredikante vergroot die gevoel van skuld, skande en woede

- minagtende optrede van Ringspredikante en doelbewuste vermyding van die respondente beklemtoon die versaking van die pastorale roeping.

Die eise wat aan pastorale sorggewers en begeleiers gestel kan word, is onder meer:

- om liefdevol en sensitief soos Jesus te wees

- omgee is belangriker as boekekennis

- kundigheid met betrekking tot arbeidswetgewing is nie onderhandelbaar nie.

Respondente het oorwegend positief gereageer op die aanname dat daar ook aan die predikant wat die tughandeling ondergaan sekere vereistes en verwagtings gestel kan word, naamlik:
- eerlikheid en openlikheid

- sonde moet nie weggesteek word nie

- maak tyd om probleme deeglik uit te sorteer

- selfondersoek is uiters belangrik

- selfbemagtiging in verskillende aspekte is noodsaaklik (byvoorbeeld arbeidswetgewing)

- selfvergifnis is baie belangrik

- waak teen die berowing van 'n toekomsvisie

- moenie bagasie bly saamdra uit die verlede nie.

\section{Bykomende inligting}

Die meeste respondente het 'n mediese dokter, sielkundige of berader besoek en die helfte het aangedui dat dit direk met die proses van die tughandeling te make gehad het.

Respondente erken die moontlike positiewe doel wat deur die tughandeling bereik kan word, maar kan dit nie in die ervaring wat hulle persoonlik daarvan gehad het, vind nie. Negatiewe kernwoorde wat uitstaan, is:

- die tug bevorder slegs die 'image' van die Kerk

- die ondersoekliggaam beskou die tughandeling as 'n reeks take wat afgehandel moet word

- die Kerk maak 'n karikatuur van die tughandeling

- die tughandeling is ' $n$ 'sirkus'

- die tughandeling is nie funksioneel nie

- die tughandeling is emosioneel vernederend

- die tughandeling is ontoepaslik.

Kernbegrippe wat die leemtes van die tughandeling, soos deur die respondente beleef, uitlig, is die volgende:

- Die tugkommissie is onbevoeg.

- Die sisteem veroorsaak spanning - dieselfde persone wat die tughandeling moet uitvoer, is ook verantwoordelik vir die pastorale begeleiding.

- Die tugkommissie is nie altyd onbevooroordeeld nie.

- Daar is selfs inmenging van persone en ander instansies tydens die tugproses.

- Die fokus is te taakgerig met die klem op die kerklike prosedures en te min mensgerig.

- Daar is ' $n$ tekort aan broederlikheid of susterlikheid.

- Die tugproses en bestaande arbeidswetgewing staan in konflik.

- Die gemeente verstaan nie altyd die tugproses nie.

- Die gemeente ly en word nie geestelik versorg in die tyd van die tughandeling nie.

- Die proses is oneerlik.

- Die proses word hanteer met die hoop dat die probleem net sal verdwyn.

- Genade ontbreek.

\section{Tematiese indruk soos gestruktureer deur die drie hoofnavorsingsvrae}

$\mathrm{Na}$ aanleiding van die literatuur- en empiriese studie word daar tot die volgende gevolgtrekkings gekom. 


\section{Gevolgtrekking 1}

Die tughandeling lewer' $n$ bydrae tot die ontstaan en belewing van skuld- en skandgevoelens by predikante

Binne die konteks van elkeen van die ses respondente se spesifieke en unieke situasie het die prosesse van die tughandeling ' $n$ ondubbelsinnige bydrae tot die belewing van skuld- en skandgevoelens gelewer. Die tughandeling funksioneer dus as 'n snellermeganisme vir die ontstaan van skuld- en skandgevoelens.

\section{Gevolgtrekking 2}

Predikante beleef die gevoelens van skuld en skande baie intens tydens die tughandeling. Hulle ervaar die emosies van skuld en skande op sowel'n positiewe as negatiewe wyse

Respondente wat aan die empiriese navorsing deelgeneem het, het ' $n$ duidelike en intense belewing van skuld- en skandgevoelens tydens die tughandeling ervaar.

'n Emosie word slegs ervaar wanneer die stimulus kognitief geïnterpreteer word en die belang daarvan as groot genoeg geag word. Gelyktydig hiermee word verskillende fisiologiese ervarings beleef wat die geïnterpreteerde stimulus as ' $n$ bepaalde emosie tipeer.

Die gevoelens is op tweërlei wyse beleef:

- Eerstens was daar die uiters negatiewe ervaring van skuld- en skandgevoelens.

- Sommige het egter ook aangedui dat daar wel positiewe aspekte in hulle belewing van hierdie emosies werksaam was.

Die meeste respondente het egter verslae gestaan oor die funksionaliteit van hierdie emosies aangesien hulle geskok en oorbluf was deur die trauma van die hele tughandeling.

Ten opsigte van skuldemosie is bevind dat:

- respondente egte skuldgevoelens ervaar het en in hulself positiewe en regstellende aksies onderneem om dit wat hulle kon regstel en verander, wel te doen

- dit blyk dat die respondente in die grootste mate hul skuldemosie nie as destruktief beleef het nie, maar verantwoordelikheid aanvaar het vir dit waaroor hulle beheer het.

Ten opsigte van skandemosie is dit so dat:

- respondente sekere aspekte van die belewing van skande as positiewe katalisator kon benut om op 'n hoër vlak te funksioneer

- die meeste respondente graag hulle verwerking van die skandemosie as positief wou aandui, maar dat die verdedigingsmeganismes wat gebruik is daarop wys dat hulle destruktiewe skandgevoelens beleef het (en nog steeds ervaar) en dat hulle dit nie suksesvol hanteer en verwerk het nie.

\section{Gevolgtrekking 3}

Daar is geen amptelike begeleiding vir predikante tydens die tughandeling nie

Daar was geen pastorale begeleiding vir die respondente tydens die tughandeling gewees nie. Hulle moes self die gevoelens hanteer en verwerk. Sommige het ander professionele hulp verkry om die fisiese en psigiese eise wat op die trauma van die tughandeling gevolg het, te hanteer:

- Die geloofsgemeenskap se basiese onderlinge sorg het in 'n geringe mate gefunksioneer deurdat enkele lidmate die predikant ondersteun het.

- Die Kerkrade het op geen wyse die verantwoordelikheid teenoor die predikant of die gemeente met betrekking tot hulle taak nagekom nie, waaronder gemeentebou en hulpverlening of begeleiding.

- Die breër kerkverband soos beliggaam in die Ring en Ringskommissie het hul taak skromelik verwaarloos en geen intensiewe pastorale begeleiding aan die respondente gelewer nie. Die basiese eis van liefde is nie eens betoon nie, maar predikante het die grootste mate van verwerping en gevoel van besmetting beleef.

\section{Tematiese indrukke en die teoretiese modelle}

Daar is twee teoretiese modelle waarteen die inligting wat tydens die onderhoude ingewin is, geïnterpreteer moet word. Die eerste model is die Emosieteorie en die tweede model is die Tugpastoraat. Die Emosieteorie beskryf die spesifieke aard en funksie van emosies met verwysing na die gevoelsbelewing van skuld en skande, terwyl die Tugpastoraat die pastorale begeleiding verken wat die Kerk tydens die tughandeling aan predikante behoort te voorsien.

\section{Emosieteorie}

Skuld en skande word tipologies geklassifiseer as onaangename innerlike bewuswordings en sluit positiewe en negatiewe funksionele ervarings in (Grasha \& Kirschenbaum 1980:198-199; Pauw 1998:58). Hierdie twee emosies word tydens traumatiese gebeurtenisse soos die tughandeling baie intens beleef. Skuld en skande kan suksesvol hanteer word, of dit kan negatiewe en destruktiewe magte word (Critelli 1987:152).

Wanneer emosies as katalisator vir gedragsmodifikasie benut word, is dit 'n geleentheid om bestaande emosie en gedrag in nuwe houdings en optrede te omskep, sodat die hantering van die lewenseise met nuwe emosionele energie en hernude toewyding kan plaasvind (Engler 1985:280). Wanneer emosies binne hierdie raamwerk van funksionaliteit verstaan word en die belewing daarvan as ' $n$ kettingreaksie beskou word, kan die doelrelevansie van die ervaring van emosies verdiskonteer word.

Skuld- en skandgevoelens het 'n eie oorsprong, aard, indeling en funksionaliteit (Davitz 2000:62-63; Wilks 
1998:167-168). Skuld fokus op die daad wat tot die gevoel lei en skande op die persoon wat die daad verrig het. Dit impliseer dat die hantering en verwerking van skuld- en skandemosie verskil. Die taak in die begeleiding van persone wat hierdie emosies beleef, sal dus wees om die positiewe aspekte daarvan te integreer en die negatiewe en afbrekende effek tot die minimum te beperk (Malouff \& Schutte 1998:3). Skuldemosie vereis ' $n$ bereidheid om verantwoordelikheid te aanvaar en daarop kan latere belydenis, vergifnis en vryspraak volg. Skande vereis ' $n$ aanvaarding van die self ten spyte van die verantwoordelikheid vir die daad wat daartoe gelei het, asook die vermyding van die gebruik van verdedigingsmeganismes om die skandemosie se effek enigsins te verminder.

Predikante beleef die emosie van skuld en skande tydens die tughandeling baie intens. Die skuldemosie is deur al die respondente op ' $n$ fisiese en kognitiewe vlak ervaar. Respondente het ' $n$ redelike mate van positiewe skuldverwerking self toegepas. Skandemosie is deur die meeste respondente in hulself en hul eie optrede raakgesien. Hulle belewing daarvan was meestal groot tot oorweldigend. Hulle het toegegee dat' $n$ hele aantal verdedigingsmeganismes in hulle hantering van die skande na vore gekom het. Die skandemosie is meestal nie suksesvol deur die respondente hanteer en verwerk nie.

Aangesien emosie egter ' $\mathrm{n}$ funksionele rol vervul, moet die predikante se ervaring van skuld en skande daarvolgens beoordeel word:

- Wat skuld betref, vervul dit die rol tot introspeksie, erkenning van skuld en die aanvaarding van verantwoordelikheid, die wek van 'n besef dat predikante ook deel is van die gebroke werklikheid, empatie en begrip vir ander, vergifnis en vryspraak, geloofsgroei, die regstel van negatiewe dinge uit die verlede en ' $n$ integrasie van die positiewe en die negatiewe (Louw 1999:471).

- Wat skande betref, vervul dit ook 'n funksie deurdat die gevoel lei tot optrede wat andersins dalk gelaat sou word, deurdat groter begrip vir ander ontwikkel word, deurdat innerlike sterkte en begrip met dieper insig groei en deurdat 'n groter vermoë om ander te help, ontstaan.

Respondente het baie gemaklik en meer geredelik oor skuldgevoelens as oor die ervaring van skandgevoelens gepraat. Die gevolgtrekking is dat hulle baie beter toegerus is om skuldemosie te hanteer as wat hulle in staat is om skandgevoelens te hanteer. Verder die bestaande en onverwerkte skandemosie weer vergroot wanneer daar selfs maar net daaroor gepraat word.

Dit het duidelik geblyk dat die oorsprong, aard, indeling en funksie van skuld en skande verskil. Die onderhoudskedule het juis hierdie onderskeid ondersoek en elke emosie afsonderlik bestudeer. Dit beteken konkreet ook dat die hantering en verwerking van die twee emosies verskillende wyses van aanpak en vaardighede vereis.

\section{Tugpastoraat}

Dit is ten diepste God wat in die pastoraat handelend met die mens in nood bemoeienis maak. God sluit egter mense by sy handelinge met mense in (Heitink 1977:21-22). In die geval van die tughandeling sou dit konkreet beteken dat God die betrokkenes tegemoet kom deur die aktiewe bemoeienis wat die geloofsgemeenskap met die noodlydende maak. Die Kerk vervul haar roeping juis in tye wanneer die nood van mense deur die sorg van die gemeente opgevang en hanteer word. Hierdie handelinge kommunikeer die bevryding wat God aan die noodlydende wil bied omdat Hy aktief ingryp en omstandighede verander.

Kerke het pastoraal onverantwoord opgetree teenoor die respondente in hierdie ondersoek. Die ervaring van isolasie, liefdeloosheid, onkerkordelike bestuur van die prosesse van die tughandeling en die optrede van kerkleiers het juis die teendeel van die liefde van Jesus Christus gekommunikeer. Telkens moes predikante ervaar dat die Kerk se spreke oor die groot dade van God deur die tughandeling tot stilswye gedwing is. Nie een van die respondente het enige ondersteuning of kommunikasie van God se bemoeienis ervaar nie. Inteendeel, die persone het deurlopend beleef dat hulle onpastoraal en onbewoë hanteer is.

Die doelstellings van geestelike leiding is die taak van die geloofsgemeenskap en moet in tye van trauma en krisis verwesenlik word (Van Iersel \& Eerbeek 2009). Die betrokke predikante het deur eie toedoen sekere geestelike doelstellings bereik en nie deur enige intervensie van die kant van die geloofsgemeenskap nie. Hulle het dikwels self tot die ontdekking gekom van nuwe geloofsinsigte, hulself opnuut aan God oorgegee en geheilig en self van die stukkende emosies iets positiefs probeer maak. Volgens die respondente was die Kerk afwesig. Onbetrokke. Liefdeloos en apaties.

Tugpastoraat word omskryf as die amptelike begeleiding (hulpverlening) tot genesing, bystand, begeleiding, versoening en koestering wat die geloofsgemeenskap aan predikante verskuldig is tydens die tughandeling deur die kommunikasie (in al sy modusse) van die evangelie van Jesus Christus. Dit het ten doel om die betrokkenes se geloofsidentiteit te bevestig, hulle tot persoonlike heiliging aan te spoor, hulle te help om deur die (her)ontdekking van die persoonlike charismata 'n nuwe diensbaarheid te vind, 'n verdieping van persoonlike geloofsinsig te bewerk en die herstel van die eenheid van die persoon te verseker. Hiervan het slegs die ondersteuning enkele gemeentelede tydens die tughandeling tereg gekom. Die uitdaging vir die Kerk in die uitvoering van hierdie taak en verantwoordelikheid is daarom baie groot.

Die korrekte mensbeskouing (Albers 1995:91-108), God se verbondsliefde wat onbegrens is (Vos 1996:96-100), die regverdiging wat slegs deur geloof plaasvind en nie deur goeie werke nie (Barth 1964; Berkhof 1973), die kruisdood van Jesus wat verlossing en versoening bewerk (Farmer 1988), 
die geloofsgemeenskap wat die draer van die boodskap van genade en vergewing is en die herderbeeld wat telkens in die Bybel voorkom (Dreyer 1981:23), is die diepste rede vir die tugpastoraat. Hierdie sake het nie aan die orde gekom tydens die tughandeling van die respondente wat tydens die ondersoek genader is nie. Hulle het deurgaans aangetoon dat dit die ideaal is, maar dat dit in die praktyk slegs woorde en teologie bly. Daar is nie hande en voete wat die boodskap na die noodlydende dra en aangee nie. Daar is wel beskuldiging, vingerwysing en teregwysing, maar geen onderwysing of rigtingwysing na die uitkoms wat God deur die Heilige Gees in Jesus Christus bied nie.

Die gemeente se onderlinge sorg, die Kerkraad se gemeentebouprogramme en die breë kerkverband se amptelike pastorale sorg word as die minimum-verwagting gestel wanneer dit by tugpastoraat ter bespreking kom (Heitink 1977:76). Hiervan kom daar egter in die praktyk weinig tot niks tereg nie. Enkele gelowiges se hulpverlening en ondersteuning vervang egter nooit die professionele en kundige begeleiding wat op alle vlakke van die noodlydende se lewe behoort te funksioneer nie. Onvoorwaardelike liefde, diens, gebede, verdraagsaamheid en vergewensgesindheid, gemeenskap en eenheid, vrede en bemoediging behoort deel te wees van elke geloofsgemeenskap se mondering wanneer iemand swaarkry en ly (Heyns 1977:90-91).

Ook aan die predikant word tydens die tughandeling eise gestel. Hiervoor sien die respondente kans en is hulle bereid om die verantwoordelikheid te aanvaar. Hulle gaan egter hiervoor hulp nodig hê. Die take wat hul moet onderneem, sluit in die erkenning van skuld en die aanvaarding van verantwoordelikheid (Lategan 1992:52), berou en belydenis (Louw 1999:471), die aanvaarding van vergifnis (ook selfvergifnis) en die uitreik en strewe na 'n nuwe lewe as getransformeerde mens (Vos 1984:378).

Die funksie van die tugpastoraat kan omskryf word as ' $n$ vyfledige taak, naamlik genesing (Strydom 2011:198), bystand (Heitink 1998:135), begeleiding tot groei en ontwikkeling (Segal 1997:235-236), versoening (Heyns 1981:282) en koestering. Alle respondente het hierdie funksie onderskryf en ook in dieselfde asem die Kerk aangekla omdat daar geen begeleiding is tot die bereiking van die strewe nie. Die Kerk sal hand in eie boesem moet steek om so te kom tot die aanvaarding van die verantwoordelikheid van die taak tot die bereiking van hierdie doelstellings.

Deurlopende begeleiding wat funksioneel, professioneel en effektief is, word vir die tugpastoraat voorgehou (Stone 1999). Hiervan kom weinig tot uitvoering wanneer die huidige tughandeling van predikante plaasvind. Daar is dus ' $\mathrm{n}$ behoefte aan beplanning, assessering, monitering, korrigering, rekordering en verslaggewing om so te kom tot 'n deursigtige, regverdige en billike tugproses.

\section{Verbeterde praktykteorie}

Die veronderstelling is dat die 'angel' van die tughandeling, naamlik die destruktiewe en negatiewe element daarvan, beheer kan word. Die tughandeling kan 'n positiewe, versterkende en geloofsopbouende geleentheid vir alle betrokke partye wees. Die evangeliedienaar se belewing van 'slagoffer' kan grootliks omkeer in 'n belewing van 'versorgde'.

Drie vereistes vir so 'n geloofskatarsis is:

- 'n suiwer teologie van die Bybelse beginsels vir die voltrekking van die tughandeling

- 'n praktyk wat deursigtig, objektief en meetbaar is

- 'n gesamentlike geestelike- en pastorale geloofspad wat alle betrokkenes in die proses verryk en in hul geloof versterk.

Skande is ' $n$ integrale deel van die emosionele belewing van die predikant tydens die tugproses in die N.G. Kerk. Daarmee gepaardgaande en onlosmaaklik verbonde is die gevoelens van skuld en verlies. Hierdie gevoelens kan veral gedurende die drie prosesse van die tughandeling, maar ook baie lank daarna, ervaar word as stigmatiserend, traumatiserend en marginaliserend.

Die predikant beleef hierdie gevoelens eerstens op amptelike, maar ook op persoonlike vlak. Die gevoelens woed verder in die dimensie van die teologiese, intellektuele, spirituele en emosionele aspekte van haar of sy persoon. Dit omsluit die predikant se hele menswees en identiteit. Die effek hiervan vir die predikant is ' $n$ afbrekende, bindende en immobiliserende negatiewe mag.

Dit is die hoë roeping van die Kerk om medeverantwoordelikheid te neem vir die uitkomste van die proses van die tughandeling en vir die pastorale versorging van die Evangeliedienaar. Die Kerk en verantwoordelike kommissies en vergaderings moet hierdie taak met die grootste nougesetheid en empatie beoefen, sodat Christus se liefde, vergifnis, genade en toekomsvisie vir die persoon(e) en Kerk daardeur verwesenlik word. In die hede moet die negatiewe van die verlede afgehandel word en die deure na die toekoms moet ontsluit word.

Die sleutelmag van die kerk moet ook aangewend word om met die verlede klaar te speel en dit te bind sodat die gelowiges saam ' $n$ nuwe heerliker toekoms kan binnegaan. Die geloofsgemeenskap het nie alleen die verantwoordelikheid om tugmatig teenoor die predikant wat in sonde geval het op te tree nie, maar ook en veral om die proses van herstel te inisieer, te beplan, te begelei, te moniteer en af te sluit. Dit is die taak van die geloofsgemeenskap om die destruktiewe krisis af te takel en om die basis van vergifnis, hoop en verwagting te skep.

Die fokus is op pastorale begeleiding wat aan sekere vereistes voldoen:

- Doelgerigte begeleiding: Die pastorale begeleiding van predikante word ten nouste verbind aan die doelstellings 
van die tughandeling naamlik die eer van God, die heil van die kerk en die behoud van die sondaar, waarby Visser (1982:122-125) die reinheid van die bediening voeg.

- Amptelike begeleiding: Onderlinge sorg, gemeentebou en professionele pastorale intervensie word onderskei.

- Funksionele begeleiding: Die uitkomste van genesing, bystand, begeleiding, versoening en koestering verkry aandag.

- Kerklike begeleiding: Dit sluit die eis van begeleiding volgens die Woord en Belydenisskrifte in.

- Holistiese begeleiding: Hiermee word die fisiese, psigiese, emosionele en geestelike eise verwoord.

- Verantwoordbare begeleiding: In die toepassing van die kerkordelike prosedures word billikheid en regverdigheid, wat die begeleidingsproses sal kenmerk, vereis.

- Prosesmatige begeleiding: Die prosesmatige aard van die tughandeling en die tugpastoraat sal deurlopend in die begeleidingsproses verreken word.

- Beperkende- en verruimende begeleiding: Die negatiewe aspekte van skuld- en skandgevoelens moet tydens die tughandeling beperk word en die suksesvolle hantering daarvan moet vergroot word.

\section{Aanbevelings}

Die volgende aanbevelings kan gemaak word:

- Die prosesse van die tughandeling moet deurentyd gemoniteer word met betrekking tot die impak wat dit op die gevoelsbelewing van skuld en skande het.

- Pastorale sorg word op alle vlakke van die geloofsgemeenskap se bestaan vereis wanneer die tughandeling van predikante ter sprake kom.

- Professionele pastorale begeleiding is onontbeerlik in die suksesvolle hantering van die trauma van die tughandeling en die hantering en verwerking van gevoelens van skuld en skande.

- Die behoud van ampsbevoegdheid en die herstel tot diensbaarheid behoort tydens die toepassing van en begeleiding tydens die tughandeling prioriteit te geniet.

\section{Erkenning \\ Mededingende belange}

Die outeur verklaar dat hy geen finansiële of persoonlike verbintenis het met enige party wat hom nadelig kon beïnvloed in die skryf van hierdie artikel nie.

\section{Literatuurverwysings}

Albers, R.H., 1995, Shame: A Faith Perspective, The Haworth Press, New York.

Barth, K., 1964, Kirchliche Dogmatik IV/2, EVZ/-Verlag, Zürich.

Berkhof, H., 1973, Christelijke Geloof, Callenbach, Nijkerk.

Britz, R.M., 1991, 'In tug moet dit méér om Christus se Heerskap gaan, minder om reëls', Die Kerkbode 148(11), 4.

Critelli, J.W., 1987, Personal Growth and Effective Behaviour, CBS College Publishing, New York.

Davits, H.J., 2000, The Language of Emotion, Academic Press, London.

De Wet, F.W., 2009, 'Die implikasies van 'n pneumatologiese-bepaalde teoretiese raamwerk vir navorsingsmetodologie in prakties-teologiese wetenskapsbeoefening', In die Skriflig 43(2), 227-250.

Dreyer, T.F.J., 1981, Poimeniek: 'n Pastorale oriëntasie, HAUM Uitgewery, Pretoria.

Engler, B., 1985, Personality theories: An introduction, 2nd edn., Houghton Mifflin Company, Boston.

Farmer, W.R., 1988, The international Bible commentary: A catholic and ecumenical commentary for the twenty-first century, The Liturgical Press, Collegeville.

Grasha, A.F. \& Kirschenbaum, D.S., 1980, Psychology of adjusment and competence: An applied approach, Winthrop Publishers, Cambridge, MA.

Heitink, G., 1977, Pastoraat als hulpverlening: Inleiding in die pastorale theologie en psyghologie, Kok, Kampen.

Heitink, G., 1993, Praktische theologie: Geschiedenis, theorie, handelingsvelde, Kok, Kampen.

Heitink, G., 1998, Pastorale zorg: Theologie - differentiatie - praktijk, Kok, Kampen.

Heyns, J.A., 1977, Die Kerk, N.G. Kerkboekhandel, Pretoria.

Heyns, J.A., 1981, Dogmatiek, N.G. Kerkboekhandel, Pretoria.

Lategan, L.O.K., 1992, 'Aard, subjek en objek van tug: Kantaantekeninge op weg na ' $n$ teologiese fundering van tug', Tydskrif vir Christelike Wetenskappe 28(3), 46-57.

Louw, J.L., 1999, Pastoraat as vertolking en ontmoeting: Teologiese ontwerp vir 'n basisteorie, antropologie, metode en terapie: Nuwe hersiene uitgawe, Lux Verbi, Kaapstad.

Malouff, J. \& Schutte, N.S., 1998, Games to enhance social and emotional skills, Charles C. Thomas Publishers, Springfield.

Niemandt, N., (Samesteller), 2007, 'Die Kerkorde van die Nederduitse Gereformeerde Kerk met Reglemente, Kerkordelike Riglyne en Funksionele Besluite soos vasgestel deur die Algemene Sinode in Oktober 2007', Lux Verbi.BM, Kaapstad.

Pauw, D.A., 1998, 'Jesus: Sy belewing en verwerking van sy emosies', Skrif en Kerk 19(1).

Pieterse, H.J.C., 1993, Praktiese teologie as kommunikatiewe handelingsteorie, RGNUitgewers, Pretoria.

Sadler, T.H.N., 1979, Die Kerklike Tughandeling, N.G. Kerkboekhandel Transvaal, Pretoria.

Segal, J., 1997, Raising Your Emotional Intelligence: A Practical Guide, Henry Holt and Company, Inc., New York.

Stone, M.F., 1999, Coaching, counselling \& mentoring: How to choose \& use the right technique to boost employee performance, AMACOM, New York.

Strydom, W.A., 2011, 'Pastoraat aan getraumatiseerde kinders in die intensiewesorgeenheid: ' $\mathrm{n}$ Gestalt benadering', DD tesis, Universiteit van SuidAfrika.

Van lersel, A.H.M. \& Eerbeek, J.D.W. (red.), 2009, Handboek: Justitiepastoraat. Context, theologie en praktijk van het Protestants en Rooms-Katholiek justitiepastoraat, Publicatiereeks van het Centrum voor Justitiepastorat, Uitgeverij DAMON Budel, 's-Gravenhage.

Visser, J., 1982, 'Die tug oor ampsdraers: 'n Kerkregtelike en kubernetiese studie', DD proefskrif in die Fakulteit Teologie, Potchefstroomse Universiteit vir Christelike Hoër Onderwys.

Vorster, J.M., 1997, 'Die kerklike tug as sleutel van die koninkryk van die hemele', Studia Historiae Ecclesiasticae V(23), 149-168.

Vos, C.J.A., 1984, 'Die Heilige Gees as kosmies-eskatologiese gawe - 'n Eksegetiesdogmatiese studie', DD proefskrif in die Fakulteit Teologie: Afdeling B (Nederduitse Gereformeerde Kerk), Universiteit van Pretoria.

Vos, C.J.A., 1996, Die volheid daarvan I, RGN-Uitgewers, Pretoria.

Wilks, F., 1998, Intelligent emotion: How to succeed through transforming your feelings, William Heinemann, London. 


\section{Bylaag 1: Gestruktureerde onderhoudskedule}

\section{Afdeling A}

Die tughandeling as proses:

1. Die kerklike tughandeling is ' $n$ reeks handelinge (prosesse) wat oor ' $n$ tydperk van jare kan strek. Watter dele van die tughandeling is van toepassing?

\section{Afdeling B}

Die tughandeling en die gevoelsbelewing van skuld en skande.

\section{Skuldgevoelens}

Skuldgevoelens is in die studie gedefinieer as 'n pynlike, innerlike gevoel wat veroorsaak word deur die selfbewuswording van konflik tussen eie optrede en die voorafooreengekome morele en sedelike kode. Skuld is ' $n$ fenomenologiese saak en het te make met die oortreding van waardesisteme. Skuldgevoelens betrek ons gedagtes, gedrag en handelinge en word fisies en kognitief ervaar:

2. Het $u$ volgens die definisie tydens die prosesse van die tughandeling skuldgevoelens beleef? Gebruik die volgende skaal: 1 = Nee; 2 = Onseker; 3 = Ja

3. Indien u op vraag 2 'Ja' geantwoord het, beskryf die intensiteitsvlak van $\mathrm{u}$ belewing van die skuldemosie tydens die tughandeling. Gebruik die volgende skaal: $1=$ Min; 2 = Redelik; 3 = Groot; 4 = Oorweldigend

4. Merk asseblief die volgende fisiese en kognitiewe uitings van die belewing van skuldgevoelens, soos dit op $u$ van toepassing was tydens die tughandeling. Gebruik die volgende skaal: 1 = Geen belewing; 2 = Min belewing; 3 = Redelike belewing; 4 = Groot belewing; 5 = Oorweldigende belewing

\section{Die ervaring van egte skuldgevoelens}

Het $u$ ' $n$ bitter en deurdringende gevoel ervaar, byna asof $u$ die bitterheid kon proe? Het u gereeld $u$ hande gewring?

Het u kop gehang en was dit moeilik om mense in die oë te kyk?

Het u pyn in die abdomen gevoel wat met angstigheid gepaard gegaan het? Het $u$ die gebeure oor en oor in u gedagtes herhaal?

Het $u$ indien $u$ die gebeue in u gedagtes herhaal het, sekere elemente van die gebeure verander om ander scenario's te skep?

Het u dikwels u self verwyt en gesê: 'As ek dit maar net nie gedoen het nie!'

5. Het $\mathrm{u}$ op enige stadium tydens $\mathrm{u}$ belewing en verwerking van skuldgevoelens bewustelik of onbewustelik die volgende vrae aan uself gestel? Gebruik die volgende skaal: 1 = Nee; 2 = Onseker; 3 = Ja

\section{Positiewe verwerking van skuldemosie}

Is ek verantwoordelik vir hierdie situasie?

Wat het ek oortree sodat ek skuldig voel?

Wat is daar wat ek kan verander?

Hoe kan ek my gedrag in die toekoms rig om soortgelyke skuldgevoelens te voorkom? Hoe kan ek dit wat ek verkeerd gedoen het, reg stel sonder om enige verdere skade te berokken?
6. Wat was u ervaring van die prosesse van die tughandeling en die effek daarvan op $\mathrm{u}$ belewing van die emosie van skuld?

\section{Skandgevoelens}

Skandgevoelens is in die studie gedefinieer as ' $n$ belewing van inherente tekorte. Dit is die belewing van mislukking. Skande word beleef as ' $n$ blootlegging van die self as ontoereikend, sleg, onwaardig. Skande is 'n selfbeoordeling van die eiewaarde. Skande is hoofsaaklik 'n ontologiese saak. Dit het te doen met ' $n$ persoon se identiteit en menswees:

7. Het $\mathrm{u}$ tydens die tughandeling, gevoelens van skande beleef? Gebruik die volgende skaal:

1 = Nee; 2 = Onseker; 3 = Ja

8. Indien $\mathrm{u}$ op vraag 7 'Ja' geantwoord het, beskryf die intensiteitsvlak van $\mathrm{u}$ belewing, van die skandemosie tydens die tughandeling. Gebruik die volgende skaal: $1=$ Min; 2 = Redelik; 3 = Groot; 4 = Oorweldigend

9. Het $\mathrm{u}$ op enige stadium tydens $\mathrm{u}$ belewing en verwerking van skandgevoelens, bewustelik of onbewustelik tot die volgende besef rakende uself gekom? Gebruik die volgende skaal: 1 = Nee; 2 = Onseker; 3 = Ja

\section{Dinamiek van destruktiewe skandgevoelens}

Ek het ' $n$ persoonlike afkeer ontwikkel in myself en was diep teleurgesteld.

Ek besef dat ek vir God, myself en baie ander mense diep teleurgestel het. Ek het gevoel dat ek deur God en mens verlaat is.

Ek is diep verneder en van my menswaardigheid gestroop.

Ek het ' $n$ belewing van gebrekkigheid, onvolkomendheid en defek ervaar. Ek het besoedel en besmet gevoel.

10.Merk asseblief al die meganismes wat $\mathrm{u}$ gebruik het om die onhoudbare ongemak van skandgevoelens te hanteer. Gebruik die volgende skaal: 1 = Nee; 2 = Onseker; 3 = Ja

Verdedigingsmeganismes in die hantering van destruktiewe skandgevoelens Strewe na perfeksionisme om te kompenseer vir die gevoel van mislukking en defek. Selfregverdiging deur eie optrede goed te praat en te verdedig. Manipulasie van die situasie/mense/feite.

Blaamverskuiwing deur skuld op ander te projekteer.

Martelaarkompleks wat vra om bejammering.

Minagting in die vorm van arrogansie, meerderwaardige houding, veroordelende en vernederende optrede.

Ontkenning van skuld.

Humor in die vorm van sarkasme en sinisme (kan ook selfvernederende humor wees) en ongeërgde vrolikheid.

Onttrekking en isolasie.

Woede soos algemene vyandiggesindheid, bitterheid, kroniese haatdraendheid of ' $n$ eksplosiewe manifestasie van woede.

11.Wat was u ervaring van die prosesse van die tughandeling en die effek daarvan op $\mathrm{u}$ belewing van die emosie van skande?

12.Het $\mathrm{u}$ op enige stadium geoordeel dat daar positiewe aspekte aan die belewing van skuldgevoelens is? Gebruik die volgende skaal: 1 = Nee; 2 = Onseker; 3 = Ja

13. Gee asseblief meer inligting.

14. Het $u$ op enige stadium geoordeel dat daar positiewe aspekte aan die belewing van skandgevoelens is? Gebruik die volgende skaal: 1 = Nee; $2=$ Onseker; $3=\mathrm{Ja}$

15.Gee asseblief meer inligting. 


\section{Afdeling C}

\section{Die tughandeling en pastorale begeleiding}

16. Hoe belangrik dink $\mathrm{u}$ is die volgende vereistes ten opsigte van die pastoraat tydens die tughandeling. Gebruik die volgende skaal: 1 = Onbelangrik; 2 =Redelik belangrik; $3=$ Nie baie belangrik, maar ook nie onbelangrik nie; $4=$ Belangrik; 5 = Uiters belangrik

\section{Vereistes ten opsigte van pastoraat tydens die tughandeling}

Suiwer teologiese antropologie en realistiese verwagtings.

Die verbond en God se aanvaarding van sondaar mense.

Regverdigmaking deur die geloof.

Die kruis as simbool van die uitwissing van skande en oneer.

Die geloofsgemeenskap as die draer van die boodskap van genade.

Herder vir die herders wat sorg benodig.

Die genade van vergifnis.

17. Hoe belangrik dink $\mathrm{u}$ is die volgende funksies van tugpastoraat? Gebruik die volgende skaal: 1 = Onbelangrik; 2 = Redelik belangrik; 3 = Nie baie belangrik, maar ook nie onbelangrik nie; 4 = Belangrik; 5 = Uiters belangrik

\section{Funksie van pastoraat tydens die tughandeling}

\section{Emosionele herstel en genesing.}

Bystand om emosioneel en geestelik te groei.

Begeleiding om vrye keuses te maak en verantwoordelikheid te aanvaar vir dit wat verby is en dit wat voorlê.

Versoening en die herstel van gebroke verhoudings.

Koestering en sensitiewe omgee.

18.Tot watter mate behoort die onderlinge sorg van die geloofsgemeenskap te funksioneer tydens die tughandeling. Gebruik die volgende skaal: 1 = Glad nie; 2 = Min; 3 = Redelik; 4 = Sterk

\section{Pastorale beginsels van begeleiding tydens die tughandeling}

Die gemeente het mekaar waarlik en onvoorwaardelik lief.

Die gemeente dien mekaar

Die gemeente bid sonder ophou vir mekaar.

Die gemeente gee met ' $n$ sagmoedige gees ag op mekaar deur te verdra en te vergewe.

Die gemeente leef in liefde met mekaar saam al is dit soms moeilik en volhard in die gemeenskap van die eenheid.

Die gemeente bewaar die vrede met mekaar.

Die gemeente bemoedig mekaar.

19. Hoe het $\mathrm{u}$ die onderlinge sorg van die geloofsgemeenskap beleef tydens die tughandeling?

20.Het iemand tydens die kerklike tughandeling $\mathrm{u}$ amptelik, pastoraal in opdrag van die Kerkraard of Ring begelei om die gevoelens van skuld en skande te verwerk?

21.Moet die pastorale sorggewers tydens die tughandeling aan die volgende vereistes voldoen? Gebruik die volgende skaal: 1 = Nee; 2 = Onseker; 3 = Ja

Eise aan die pastorale sorggewers gestel met begeleiding tydens die tughandeling Liefdevolheid

Empatiese meelewing

Egtheid

Betroubaarheid

Emosionele en geestelike volwassenheid

Toeganklik en beskikbaar

Omgee geaardheid

Onvoorwaardelike aanvaarding

Geduldig

Respek en eerbied vir ander

Professioneel

Toegerus om pastorale verantwoordelikhede te verrig (fokus op tughandeling)
22. Hoe belangrik dink $\mathrm{u}$ is die volgende eise wat aan ' $\mathrm{n}$ predikant gestel kan word tydens die tughandeling? Gebruik die volgende skaal: 1 = Onbelangrik; 2 = Nie baie belangrik; 3 = Nie minder belangrik, maar ook nie meer belangrik nie; 4 = Belangrik; 5 = Baie belangrik

Eise aan die predikant gestel met begeleiding tydens die tughandeling Beskerm die privaatheid met balans van openheid en eerlikheid Erken die skuld en aanvaar die verantwoordelikheid Toon egte berou

Doen volledige belydenis

Ontvang onvoorwaardelike vergifnis

Begin ' $n$ nuwe lewe

Verwerk die gevoelens van skuld en skande

23.Watter ander eise of vereistes kan volgens $\mathrm{u}$ aan die predikant gestel word tydens die tughandeling?

\section{Afdeling D}

\section{Die tughandeling en addisionele informasie}

24. Het $\mathrm{u}$ in die tydperk van die tugverhoor of in die maande daarna 'n dokter besoek?

25.Was daar 'n verband tussen dié besoek(e) en die tughandeling?

26.Indien 'Ja', voorsien meer inligting.

27. Het $\mathrm{u}$ in die tydperk van die tughandeling 'n sielkundige of ander professionele persoon gekonsulteer?

28. Indien ' $\mathrm{Ja}^{\prime}$, voorsien meer inligting.

29.Dink u dat die tughandeling van predikante die doel soos verwoord in Artikel 59, bereik? Gebruik die volgende skaal: 1 = Nee; 2 = Onseker; 3 = Ja

Beantwoord die tughandeling aan die doel volgens Artikel 59

Die tughandelig is tot die eer van God.

Die tughandeling is tot die heil van die Kerk.

Die tughandeling is tot die behoud van die sondaar.

30.Beoordeel die volgende stelling na aanleiding van $u$ eie belewing van die tughandeling. Gebruik die volgende skaal: 1 = Ontoepaslik; 2 = Nie ontoepaslik nie, maar ook nie toepaslik nie; 3 = Toepaslik

Stellings in verband met die tughandeling

Tug is terapeuties deurdat dit die persoon met Christus wil versoen.

Tug is ' $n$ konstruktiewe poging/optrede om die kwaad teen te gaan.

31.Wat is volgens $u$ oordeel die leemtes ten opsigte van die huidige tughandeling van predikante?

32.Watter aanbevelings kan $\mathrm{u}$ maak ten opsigte van die verbetering van die pastorale begeleiding van predikante tydens die tughandeling soos dit spesifiek met die verwerking van gevoelens van skuld en skande verband hou?

33.Lys enige ander onderwerpe ten opsigte van die tughandeling van predikante wat volgens $\mathrm{u}$ mening ook wetenskaplik nagevors behoort te word? 